


\title{
Marriage Market Responses in the Wake of a Natural Disaster in India
}

\author{
Shreyasee Das \\ Department of Economics \\ Temple University \\ Shatanjaya Dasgupta \\ Department of Economics \\ Beloit College
}

Department of Economics

DETU Working Paper 19-02

July 2019

1301 Cecil B. Moore Avenue, Philadelphia, PA 19122

http://www.cla.temple.edu/economics/faculty/detu-working-paper-series/ 


\title{
Marriage Market Responses in the Wake of a Natural Disaster in India
}

\author{
Shreyasee Das* $\quad$ Shatanjaya Dasgupta ${ }^{\dagger}$
}

May 2, 2019

First Version: July 31, 2018

\begin{abstract}
With increasing occurrences of natural disasters globally, there is a need to study their demographic effects both in the short- and long-run. In the backdrop of the $2001 \mathrm{Gu}$ jarat earthquake that resulted in over 20,000 casualties and large-scale loss of property, this paper analyzes marriage market responses in the event of a natural disaster. Using the 2004-05 round of the India Human Development Survey and employing a differencein-differences strategy, we find a statistically significant reduction in women's marriage age, a lower probability of marital matches within the same villages, a decrease in spousal educational difference and probability of marrying a husband with more education, and an increased likelihood of women marrying into poorer households. Additionally, we discuss how our results could be affected by several channels and provide empirical evidence on changes in dowry payments as a potential mechanism.
\end{abstract}

JEL Codes: J12; J16; O53

Keywords: Marriage; India; Gujarat Earthquake

\footnotetext{
*Department of Economics, Temple University, Email: shreyasee.das@temple.edu

${ }^{\dagger}$ Department of Economics, Beloit College, Email: shatanjaya.dasgupta@gmail.com. Helpful comments from Francisca Antman, Nayana Bose, Cher Li, Terra McKinnish, Vidhya Soundararajan, seminar participants at the 2018 Annual Conference on Economic Growth and Development at ISI Delhi, 2018 Eastern Economic Association meetings, 2018 Southern Economic Association meetings, 2019 Midwest Economic Association meetings, as well as the Economics Departments of Providence College and Towson University are gratefully acknowledged. We thank Sula Sarkar for providing help with ArcGIS and the map of India.
} 


\section{Introduction}

Globally, 7,474 natural disasters have been recorded between 1998-2018 (Ritchie and Roser, 2019). Caused by environmental factors, natural disasters are severe and unexpected adverse events that often result in significant loss of life and property. The average economic loss from these events is estimated to be between US $\$ 250$ billion and US $\$ 300$ billion annually (United Nations, 2015). While there is no significant difference in the frequency of occurrence of natural disasters between the developing and developed world, the effects vary vastly among them. Better institutions, higher literacy rates, higher GDP per capita and an open economy are some of the factors that help countries recover from the devastating effects of natural disasters (Kahn, 2005; Noy, 2009). Among many macroeconomic outcomes, these disasters can affect fiscal and trade deficits (Heger, Julca and Paddison, 2008), flow of capital (Yang, 2008), unemployment rates (Lynham, Noy and Page, 2017), and long-run growth (Skidmore and Toya, 2002, Strobl, 2012). The impact of natural disasters also vary significantly within countries, by age, gender, and socioeconomic status, reflecting the differences in vulnerability across these dimensions (Frankenberg, Laurito and Thomas, 2014). While some studies show that post-disasters, women and girls face a lower life expectancy (Neumayer and Plümper, 2007), higher likelihood of being underweight and stunted (Datar et al., 2013), lower levels of educational attainment (Caruso and Miller, 2015, Paudel and Ryu, 2018) and that younger children face higher risks of declines in health indicators (Thamarapani, 2017, Caruso, 2017), others find opposing results. For example, Datar et al. (2013) find that infants are less vulnerable to health shocks in India while Takasaki (2017) finds that school enrollment is lower for boys than girls amongst cyclone victims in rural Fiji .

We contribute to this literature by providing a comprehensive look at marriage outcomes following the 2001 Gujarat earthquake in India that resulted in approximately 20,000 casualties. Specifically, we examine the earthquake's impact on the age at marriage of a woman and her spouse, her autonomy in the choice of spouse, the quality of the match (measured by education and economic status), and the location of her marital household. While a burgeon- 
ing strand of literature has examined the impact of natural disasters on fertility, sex-ratio, birth-spacing (Saadat, 2008; Finlay, 2009, Zhao and Reimondos, 2012, Hamamatsu et al. 2014; Caruso and Miller, 2015; Nobles, Frankenberg and Thomas, 2015, Nandi, Mazumdar and Behrman, 2018), birth weight (Torche, 2011), schooling (Caruso and Miller, 2015), and health indicators (Mazumdar et al., 2014, Thamarapani, 2017), relatively few papers have focused on marriage outcomes. For instance, Almond et al. (2007) have shown that the Chinese famine (1959-1961) lowered the quality of marital matches since women ended up marrying spouses with less education. Using the same setting, Brandt, Siow and Vogel (2016) found that the marital attractiveness of the famine-born cohort was reduced due to adverse health outcomes faced by that cohort. Natural disasters can also change marriage and divorce rates (Cohan and Cole, 2002; Hamamatsu et al., 2014). Age at marriage has also found to be affected by armed conflicts (Shemyakina, 2009) as well as weather shocks Corno, Hildebrandt and Voena, 2017). In addition, Mobarak, Kuhn and Peters (2013) find a lower likelihood of consanguineous marriages in households that are protected by the construction of a flood embankment in rural Bangladesh.

India provides a unique setting to examine the formation of marriages due to several entrenched features in the marriage market. First, an exceedingly high proportion of marriages continue to be family-arranged in India (Rubio, 2014). Women tend to marry more educated men (educational hypergamy), although this trend is on the decline. Irrespective of marriages being self-arranged or family-arranged, caste homogamy or positive matching with respect to caste prevails (Allendorf and Pandian, 2016). Furthermore, consanguineous marriages or marriages between close blood relatives is also very common Anukriti and Dasgupta, 2018). Finally, marriages in India continue to be characterized by increased dowry payments Anderson, 2003; Chiplunkar and Weaver, 2017). A negative financial shock brought on by a disaster can usher in changes to the above-mentioned patterns. For example, it can augment the cost of marrying a daughter due to increased dowry payments or not finding quality matches as would have previously been intended. 
We use the 2004-2005 wave of the India Human Development Survey, a nationally representative dataset, to conduct our empirical examination of the marriages formed postearthquake. We exploit the district-cohort variation in exposure to the earthquake and rely on a difference-in-differences estimation strategy. Our results indicate that the earthquake reduced the age of marriage for women, lowered their probability of marrying within the same village, reduced spousal educational difference and the probability of marrying a moreeducated husband, and increased the probability of marrying into poorer households and being related to the spouse prior to marriage in affected districts compared to unaffected districts. We also account for the intensity of the earthquake to explore whether or not the most severely affected districts in Gujarat drive our results. Additionally, we discuss mechanisms underlying our results and provide empirical evidence on changes in dowry payments as a potential channel.

One conceivable threat to our analysis is the issue of migration. If migration rates due to marriages are significant, we run the risk of incorrectly identifying women in the affected and unaffected districts. Our results would be susceptible to a downward bias if the women from the affected regions end up in unaffected areas after the earthquake.1 However, Chiplunkar and Weaver (2017) document that more than three-quarters of marriages in India are within the same district. Marrying outside of one's state is even more uncommon-around 4\% (Roy, 2015, Nandi, Mazumdar and Behrman, 2018). Munshi and Rosenzweig (2009) argue that out-of-state migration is often restricted due to social networks and language barriers; these in-network (within villages/districts) marriages also provide families with much needed insurance and risk-sharing. Thus, the possibility of migration affecting our analysis appears to be trivial.

The remainder of the paper is structured as follows. Section 2 provides background information on the 2001 earthquake in Gujarat. Section 3 describes our data, presents descriptive statistics, and details the construction of variables used in this analysis. Section

\footnotetext{
${ }^{1}$ Migration in the reverse direction, that is, from unaffected regions to affected districts, would likely be absent or very negligible following the earthquake.
} 
4 outlines the empirical strategy, and the results are presented in Section 5 . Section 6 provides a discussion of possible mechanisms for our results. We conclude in Section 7.

\section{The 2001 Gujarat Earthquake}

At approximately 8:46 am on January 26 2001, an earthquake of magnitude $M_{w} 7.7$ (6.9 on the Richter scale) struck the Kutch region of Gujarat, a state in western India. ${ }^{2}$ The epicenter was $20 \mathrm{~km}$ northeast of the town of Bhuj that bore the brunt of the devastation. Upwards of 1,000 aftershocks of $M_{w} \geq 3$ plagued the region for about 2 years, with the largest one recorded at $M_{w} 6$ just two days after the main event.

Twenty-one out of 25 districts in Gujarat were affected with varying degrees of intensity. The severely affected districts included Ahmedabad, Jamnagar, Kutch, Patan, Rajkot, and Surendranagar. Less affected districts are: Amrelli, Anand, Banaskantha, Bharuch, Bhavnagar, Gandhinagar, Junagadh, Kheda, Mehsana, Navasari, Porbandar, Sabarkantha, Surat, Vadodara, and Valsad. Only four districts in the state were completely unaffected: Dahod, Dangs, Narmada, and Panch Mahals. Figure 1 provides a visual guide to the districts and the intensity of the earthquake in Gujarat.

The earthquake brought large-scale devastation in the region and affected 16 million people. The extent of devastation spread across 7,900 villages in 18 towns (Lahiri et al., 2001; Sinha, 2001). The reported loss of lives was approximately 20,000, and around 165,000 people were injured, and more than 200,000 were rendered homeless (Lahiri et al., 2001; Sinha, 2001; Narayan and Sharma, 2004). Approximately 10,000 adults (roughly equal numbers of males and females) between 15-59 years died, reducing the pool of both productive individuals and potential spousal matches (Lahiri et al. 2001). 3 The quake destroyed close to 300,000 buildings, damaged another 700,000 and caused damages to 14 earth dams in the region

\footnotetext{
${ }^{2} M_{w}$ denotes the moment of magnitude scale used to measure the size of an earthquake. It replaced the oft-used Richter scale

${ }^{3}$ Due to a lack of official data on the gender and age composition of the casualties, Lahiri et al. (2001) use population information from the 1991 Census to calculate the numbers.
} 
(Madabhushi and Haigh, 2005). The estimated economic loss was in the vicinity of US $\$ 2$ billion (Sinha, 2001).

To our knowledge, only three studies have examined the socioeconomic consequences of the Gujarat earthquake. Lahiri et al. (2001) provides an overview of the larger economic impact of the disaster. Two other papers, Finlay (2009) and Nandi, Mazumdar and Behrman (2018) evaluate the earthquake's impact on fertility, sex ratio, and birth spacing. While Finlay (2009) does not find any significant changes in a woman's fertility, Nandi, Mazumdar and Behrman (2018) find an increase in the rates of childbirth, a decrease in birth-spacing among uneducated women and in incidence of male births among rural women. Our paper adds to the understanding of the demographic consequences of this earthquake by examining its impact on marriage outcomes.

\section{$3 \quad$ Data and Descriptive Statistics}

Data for our analysis come from the 2004-05 round of the India Human Development Survey (IHDS), a nationally representative sample consisting of 41,554 households from 25 states and union territories of India that covers 1,504 villages and 970 urban neighborhoods from 383 districts. The survey collects a rich array of information on household characteristics such as religion, caste, household income, and detailed individual characteristics including age, gender, and completed years of schooling. Pertinent to our study, the IHDS interviews an eligible woman in each household; eligible women are married women between the ages of 15-49. These women were asked questions about their marital history and involvement in mate selection, IHDS being the only nationally representative survey to collect information on women's involvement in marriage-related decision making.

We limit our sample to four states: Gujarat and the bordering states of Maharashtra, Madhya Pradesh and Rajasthan. Based on information from Lahiri et al. (2001), 21 out of 25 districts in Gujarat were affected by the quake. The remaining four districts in Gujarat 
together with the districts in the three neighboring states were unaffected by the earthquake (see Figure 1). Similar to Nandi, Mazumdar and Behrman (2018), our comparison group comprises of the three neighboring states so as to keep the socioeconomic and cultural differences between the affected and unaffected districts at a minimum. Next, the survey documents a woman's year of marriage, allowing us to categorize women into two cohorts: those who were married after the 2001 Gujarat earthquake and hence whose marriage formations could potentially have been negatively affected, and those whose marriages were already formed before the disaster. Therefore, we additionally restrict our sample to marriages that took place between 1996 and 2005 or approximately five years prior to and after the earthquake. We also drop women who have been married more than once since these marriages are likely to be quite different than first marriages.

Descriptive statistics for the study sample are presented in Table 1. $4^{4}$ Age of an individual is measured in years. Educational attainment is measured as completed years of education. The raw data indicates that women and their spouses in the affected districts are, on average, older and more educated than those in the unaffected districts. Religion is divided into three groups: Hindu, Muslim and Other. The majority of sample in both groups of districts belong to the Hindu community. Caste is divided into four categories: general, scheduled caste (SC), scheduled tribe (ST) and other backward class (OBC). The latter three are the historically disadvantaged caste groups in India since they fall at the bottom of the caste hierarchy. The statistics on log of household income and monthly consumption per capita indicate that women in the affected districts are relatively wealthier compared to their counterparts in the unaffected districts. Urban is an indicator for the location of households: the sample statistics reveal that $51 \%$ of women in the affected districts reside in urban areas versus $33 \%$ in the unaffected districts.

We draw our outcome variables from the section in the survey dedicated to the demographic and household characteristics of the eligible women. In Table 2, we present descrip-

\footnotetext{
${ }^{4}$ Descriptive statistics are presented for the pre-earthquake and post-earthquake period combined. We conduct a test of the parallel trends assumption in Section 5.4.
} 
tive statistics for these variables, and again the sample is divided by whether districts were affected by the earthquake or not. Specifically, our analysis examines 13 dependent variables: a woman and her spouse's age at the time of marriage, spousal age difference, an indicator for whether her marital and natal households are in the same village, an indicator for whether she belongs to the same caste as that of her husband, difference in spousal education levels, an indicator for whether her spouse is more educated than her, an indicator for whether the economic status of her marital household is worse off compared to her natal family, three indicators for type of marriage, and indicators for whether a woman knew her husband before the wedding day or was related by blood to him (for example, uncle or cousin) prior to marriage. Following Allendorf and Pandian (2016), marriages are categorized into three types and are derived from two survey questions that women were asked to elicit information on the mate selection process. The first question asked was "Who chose your husband?" Women responded that the choice was either made by herself, together with her parents, only by her parents or only by "others" (extended family members or individuals outside the family). Only when women responded that parents or others chose their spouses alone was the question "Did you have any say in choosing him?" asked to which they could respond "Yes" or "No". If a woman reported that she chose her own husband, then the marriage is labeled as "self-arranged" marriage. If she responded that she chose her husband together with her parents or if parents or others chose a woman's spouse and she had a say in choosing him, then the marriage is labeled as "parent-arranged with consent of woman". If a woman's parents chose her spouse and she had no say in the choice, the marriage is labeled as "parentarranged without consent of woman". These three categories thus represent marriage types ranging from one in which women made the decisions to one in which they had no say at all in the choice of their spouse and their parents or others made the decisions. Overall, these outcome variables help us analyze marital matching patterns as well as the quality of the matches. 


\section{Empirical Strategy}

The main objective of this study is to analyze the effects of a natural disaster on the marriage market. There are two sources of variation on how the 2001 Gujarat earthquake could affect women's marriage outcomes. First, there is a time component: the cohort of women who were married after the earthquake versus those already married before an unexpected negative shock. The next source of variation is geographical: earthquake affected districts in Gujarat vis-a-vis the remaining districts of Gujarat and all districts in the three neighboring states of Rajasthan, Madhya Pradesh, and Maharashtra that were not affected by the earthquake. Our basic empirical strategy can be summarized by the following equation:

$$
\begin{array}{r}
y_{i d t}=\alpha_{0}+\alpha_{1}\left(\text { Affected }_{d} * \text { Post }_{t}\right)+\alpha_{2}\left(\text { Affected }_{d}\right)+\alpha_{3}\left(\text { Post }_{t}\right)+\mathbf{X} \pi+ \\
\theta_{s}+\lambda_{t}+\gamma\left(\text { State }_{s} * \text { Year }_{t}\right)+\epsilon_{i d t}
\end{array}
$$

where $y_{i d t}$ is the marriage outcome of woman $i$ in district $d$ in year $t$. Affected $d_{d}$ is an indicator variable for whether a district was impacted by the earthquake or not. Post is a dummy variable equals one for marriages that took place between 2001 and 2005, and is equal to zero for marriages between 1996-2000.5 The difference-in-differences coefficient is $\alpha_{1}$, which gives the differential impact of the earthquake in the affected districts compared to the unaffected districts. The vector of household characteristics is given by $\mathbf{X}$ and includes caste and religion indicators, dummy for urban location of the household, log of the household's total income and log of monthly consumption per capita. Base groups in the regression are general caste, Hindu religion, and rural household location. $\theta_{s}$ and $\lambda_{t}$ are state and year of marriage fixed effects respectively and are included to capture any heterogeneity at the state-level and in aggregate time trends. We also include State $_{s} *$ Year $_{t}$ fixed effects to soak up any differential time trends across states. $\epsilon_{i d t}$ is the error term.

The above analysis estimates the net effect of the earthquake on marriage outcomes.

\footnotetext{
${ }^{5}$ We include marriages from 2001 as well since the earthquake took place in the beginning of the year on January 26, 2001.
} 
However, the negative shock of a natural disaster can affect families differentially based on the intensity of the earthquake in their area of residence. For example, households in districts with extreme devastation may suffer more economic losses and household member deaths thereby finding it harder to recover than those residing in areas of less destruction and damage. Accounting for the information on earthquake intensity presented in Lahiri et al. (2001) and shown in Figure 1, we modify Equation 1 to incorporate this heterogeneity in impact. The revised regression equation we estimate is as below:

$$
\begin{gathered}
y_{i d t}=\beta_{0}+\beta_{1}\left(\text { MostAffected }_{d} * \text { Post }_{t}\right)+\beta_{2}\left(\text { LessAffected }_{d}\right)+\beta_{3}\left(\text { MostAffected }_{d}\right)+ \\
\beta_{4}\left(\text { LessAffected }_{d} * \text { Post }_{t}\right)+\beta_{5}\left(\text { Post }_{t}\right)+\mathbf{X} \pi^{\prime}+\theta_{s}+\lambda_{t}+\gamma\left(\text { State }_{s} * \text { Year }_{t}\right)+\epsilon_{\text {idt }}^{\prime}
\end{gathered}
$$

where MostAffected $_{d}$ equals one for the 6 districts in Gujarat that were severely affected. Similarly, LessAffected $d_{d}$ is an indicator for the districts that were classified as moderately impacted by the earthquake. The comparison group comprises of the unaffected districts in Gujarat and the three neighboring states. Thus, $\beta_{1}$ gives the difference-in-differences impact of the earthquake in severely affected districts while $\beta_{2}$ gives the differential impact on less severely affected districts. As before, $\mathbf{X}$ represents a vector of household controls, and we include state, year of marriage, and $S t a t e_{s} * Y_{e a r}$ fixed effects. In all our regressions, we apply the survey sampling weights and use robust standard errors that are clustered at the district level.

Before continuing on to our results, it is important to consider a few limitations of this study. First, the dataset collected information from only 383 out of 602 districts in India. For example, it omits eight districts in Gujarat: five less severely affected and three unaffected districts. Thus, our analysis is restricted to those districts for which data are available. Second, IHDS only interviews only one eligible woman per household and so we are unable to extend our study to other women in these families whose marriage outcomes might also have been impacted by the earthquake. Third, in an analysis of marriage market outcomes, it is imperative to control for women's natal family characteristics such as the educational 
level of their parents. However, this information is not available from our survey dataset. Finally, unlike other large Indian surveys such as the District Level Household Survey or the National Family and Health Survey, the IHDS has a relatively smaller sample size, limiting our ability to conduct regressions on subsamples to examine heterogeneous treatment effects.

\section{Results}

\subsection{Effects on Marriage Outcomes}

The results from estimating Equation 1 are presented in Tables 3A and 3B. The first row gives the difference-in-differences impact of the earthquake on the affected districts compared to the unaffected districts. Turning to Table 3A, we find significant effects of the earthquake on the probability of the spouse being from the same village, difference in spousal education, probability of spouse being more educated than the woman, and probability of the woman's marital family being economically worse off compared to her natal family. Controlling for household characteristics, we find a 6.5 percentage point reduction in the probability of the spouse being from the same village as the woman across the two time periods (2001-2005 versus 1996-2000) in the earthquake-affected districts compared to the unaffected districts. Similarly, spousal educational difference is found to reduce by an average of 1.56 years and there is a 25 percentage point decline in the probability that a woman's spouse is more educated than her. There is a 13 percentage point increase in the likelihood of women marrying spouses whose families are poorer than their natal families. The effects on age at marriage, spousal age difference, and probability of marrying within the same caste are statistically indistinguishable from zero. In Table 3B, we find a 26 percentage point reduction in the probability of self-arranged marriages coupled with an almost equivalent increase in the probability of parent-arranged marriages with the consent of women. While no statistically significant results are obtained for the probability of arranged-marriages without the consent

of woman, and probability of knowing spouse, we do see an 17 percentage point increase in 
the spousal match being among relatives.

\subsection{Results by Intensity of Earthquake}

The above-mentioned results may mask the nuanced effects of the disaster since the estimation equation does not take into account the intensity of the earthquake. Therefore, we turn to our next set of results from estimating Equation (2) that incorporates heterogeneity in the impact of the earthquake. The first two rows in Tables $4 \mathrm{~A}$ and $4 \mathrm{~B}$ give the difference-indifferences impact of the earthquake on the most-affected and less-affected districts respectively. In Table 4A, we find that the marriage age for women decreases by an average of 1.4 years in most-affected districts. This, in turn, also increases the spousal age difference. Regardless of the intensity of earthquake, our results indicate a reduction in the probability of matches within the same village. Likewise, the results on lower spousal educational gaps and probability of spouse being more educated, combined with an increase in the probability of women marrying men from poorer households hold irrespective of whether the district was severely or less affected. In Table 4B, the results for marriages that were self-arranged and those that were parent-arranged with the women's consent are similar in magnitude to that in Table 3B, even after differentiating the districts based on intensity of the earthquake. The last column also uncovers an increase in the probability of women being related to their spouses in less-affected districts compared to unaffected districts. However, although the coefficient on Post $*$ MostAffected is positive (0.081), it is not statistically significant.

To answer the question on whether severity of the earthquake affected marriage market outcomes, we conduct an F-test to determine if the coefficients on the terms Post $*$ MostAffected and Post $*$ LessAffected are statistically different from each other. From the test-statistics (not reported), we are unable to reject the null hypothesis of equality of the two coefficients. Therefore, we can conclude that the results are not affected by severity of the disaster and what matters for a marriage market response is whether one faced the negative shock or not. 


\subsection{Robustness Checks}

A natural disaster such as an earthquake is, indeed, an exogenous shock. However, it may be the case that certain confounding factors could be present in the earthquake-affected districts or unaffected districts, in which case our estimates will be rendered biased. Again, our results could be dependent on our choice of study period. To assuage such concerns, we conduct a series of robustness checks. First, we estimate regressions based on Equation (1) in which we simulate false locations for the earthquake. In three sets of regressions, we designate districts in the states of Rajasthan, Maharashtra, and Madhya Pradesh respectively as the treatment area. These results, presented in Appendix Table A1, reveal that the coefficients are largely statistically insignificant. Next, we test the sensitivity of our results to the choice of control states and estimate modified regressions based on Equation (1) in which we drop the states of Rajasthan, Maharashtra, and Madhya Pradesh respectively one at a time from the control group. From Appendix Table A2 we find that these results are largely similar to those presented in Tables 3A and 3B. Finally, we also test the robustness of our results by estimating regressions based on Equation (1) for additional study periods: from 1998 to 2003 (a shorter time period), and from 1991 to 2005 (a longer time period). These results are given in Appendix Table A3. Although we lose statistical power due to a smaller sample size for the time period between 1998 and 2003, it is reassuring that the results from both sets of regressions are analogous to our main results presented in Tables $3 \mathrm{~A}$ and $3 \mathrm{~B}$.

\subsection{Parallel Trends Analysis}

To accurately interpret the results of a difference-in-differences estimation, it is imperative that the parallel trend assumption holds. In other words, we must confirm that the trends in the outcome variables for the affected and unaffected districts are not statistically different in the pre-earthquake era. In the spirit of Angrist and Pischke (2009), we test this necessary condition in the following way. First, we limit the years of marriage between 1990 and 2000. Next, we estimate a time trend variable $t$ and interact it with the indicator for 
affected districts. Then, we estimate a regression similar to Equation (1) with the different marriage outcomes as the dependent variables and the indicator for earthquake-affected districts $($ Affected $)$, time trend $(t)$, and the interaction term $(t *$ Affected $)$ as our independent variables. The vector of controls denoted by $\mathrm{X}$ as well as state and year of marriage fixed effects are also included in the estimation equation. The coefficients on the interaction term from these regressions are presented in Appendix Table A4. If these coefficients are statistically equal to zero, the parallel trends assumption will be satisfied Angrist and Pischke, 2009). In fact, we do find this coefficient to be statistically equal to zero in nearly all the cases where we obtain statistically significant results (difference-in-differences coefficients). The only exceptions are the coefficient on parent arranged marriages with and without the consent of the woman..$^{6}$ Thus, we can reasonably expect the parallel trend assumption to hold, which testifies to the validity of our empirical strategy.

\section{Possible Mechanisms}

There are several channels through which an earthquake can affect marriage market outcomes. Parents may rush to marry off their daughters when faced with a negative economic shock since there would be one less mouth to feed. But this inevitably implies that households with sons (who also faced the negative shock) are willing to take in these daughters. So why might these sets of households behave in different ways? A likely reason is that households with sons would gain economically with the provision of dowries, which might help mitigate the effects of the negative shock. The greater percentage of deaths and devastation in the affected areas could lead altruistic parents to find spouses for their daughters from another village to shield them against this shock (out-of-network marriages). Either or both of these reasons could also explain the shift from self-arranged to parent-arranged marriages. Unfortunately, due to lack of information on women's parents, we are unable to test these hypothesized mechanisms.

\footnotetext{
${ }^{6}$ For these two outcomes, we are therefore unable to draw a causal inference of impact of the earthquake.
} 
Natural disasters could also bring about "marriage squeeze" effects if they lead to mismatches in the number of potential brides or grooms. Although precise data is not available, Lahiri et al. (2001) estimate that equal proportions of men and women died in the ages 15-59 years, which makes it unlikely that the earthquake altered the marriage market sex ratio. Next, the result that spousal educational difference decreases or that women become less likely to marry a spouse more educated than her could be driven by a few reasons. One possibility could be that the earthquake directly affected the educational attainment of men and women because the infrastructure needed to further one's education, for example, school buildings, were destroyed. Another reason could be that young adults were forced to pursue employment opportunities to offset the negative economic shocks faced by their families. However, analysis of our study sample in the post-earthquake era reveals that less than $2 \%$ of women and less than $1 \%$ of men attended an educational institution in the five years leading up to their wedding. This suggests that the earthquake did not affect educational investments; only that matching with respect to educational attainment differed post-earthquake.

Finally, the result that women become more likely to marry into poorer households could be explained by the effects of the earthquake on dowry payments. Since direct information on dowries is not collected by the IHDS, we make use of a proxy variable. The IHDS asks women "Generally in your community for a family like yours, what are the kinds of things that are given as gift at the time of the daughter's marriage?" Of the different options, we focus on the information on "Gold" and "Cash" since these are the two most common elements of dowry payments. We construct indicator variables with a value of one if women responded that gold or cash is sometimes or usually given and a value of zero if it is rarely or never given. Our conjecture is that women's response to this question will be largely driven by their own wedding (and hence dowry) experience. Therefore, we estimate regressions based on Equations (1) and (2) but with this indicator variable on gold or cash gifts as our dependent variable. The coefficients on the interaction term are presented in Table 5, Panel 
A presents the overall effect of the earthquake and Panel B accounts for the intensity of the disaster. Columns (1) and (2) indicate that the earthquake increased the probability of giving gold or cash at the time of daughter's marriage and these results are true regardless of the intensity of the earthquake. To make better sense of these estimates, we divide our sample into a) women who married into poorer families; and b) women whose marital households have a higher or same economic status as their natal families. Columns (3) and (4) present the results for the first subsample: the estimates indicate that dowry payments in the form of gold or cash are discounted when women marry into poorer households. Results from the Columns (5) and (6) show that the probability of giving gold or cash during the time of daughter's marriage increases when women marry into richer households or into households of the same economic status. This suggests that changes in dowry payments could be linked to the quality of matches with respect to socio-economic status. The result on increased likelihood of being related to spouse prior to marriage could also be driven by dowry payments. In fact, previous studies have found a negative association between dowry levels and the probability of consanguineous marriages (Do, Iyer and Joshi, 2013; Mobarak, Kuhn and Peters, 2013). Thus, if an exogenous shock that negatively affects earnings and livelihood reduces the amount of dowry parents can afford, marrying off daughters to blood relatives could emerge as an attractive option since lower dowry amounts are required for these matches.

\section{Conclusion}

Exploiting the 2001 Gujarat earthquake as a quasi-natural experimental setting, this paper investigates the impact on the marriage market following a natural disaster in India. The empirical analysis is carried out using data from a nationally representative survey, and we rely on a double difference estimation strategy. Our results indicate a lower age at marriage for women, lowering of the probability of marrying someone from the same village, a reduced 
spousal educational gap and probability of marrying a spouse with more education, and increasing of the probability of women marrying into poorer households and being related to the spouse prior to marriage in earthquake-affected districts compared to unaffected districts. These results stand the test of a series of robustness checks. We explore how several underlying channels could affect our results and provide empirical evidence on changes in dowry payments as the driver of our results. Thus, together with previous literature (Lahiri et al., 2001; Finlay, 2009, Nandi, Mazumdar and Behrman, 2018), our findings on the marriage market post-disaster help paint a comprehensive picture of the demographic effects of the Gujarat earthquake. These results are also notable because a woman's marital prospects (age at marriage, family-arranged marriages, spousal attributes, and characteristics of the marital home) have important implications on her subsequent life outcomes and well-being as well as that of her children, including the likelihood of facing domestic violence, autonomy in decision-making, and control over fertility (Bloch and Rao, 2002; Jensen and Thornton, 2003; Dasgupta, 2014; Rubio, 2014)

Overall, our paper contributes to a growing, yet small, literature that estimates the welfare effects of natural disasters. Households can respond to the negative shock brought about by an unpredictable and devastating event such as an earthquake by making various changes, including in the marriage market. As our findings uncover, these changes are quite substantial and relevant, and need to be taken into account by policymakers looking to formulate comprehensive disaster management policies. 


\section{References}

Allendorf, Keera, and Roshan K. Pandian. 2016. "The Decline of Arranged Marriage? Marital Change and Continuity in India." Population and Development Review, 42(3): 435464.

Almond, Douglas, Lena Edlund, Hongbin Li, and Junsen Zhang. 2007. "LongTerm Effects of the 1959-1961 China Famine: Mainland China and Hong Kong." National Bureau of Economic Research Working Paper 13384.

Anderson, Siwan. 2003. "Why Dowry Payments Declined with Modernization in Europe but Are Rising in India." The Journal of Political Economy, 111(2): 269-310.

Angrist, Joshua D., and Jörn-Steffen Pischke. 2009. Mostly Harmless Econometrics: An Empiricist's Companion. Princeton University Press.

Anukriti, S., and Shatanjaya Dasgupta. 2018. "Marriage Markets in Developing Countries." In Oxford Handbook of Women and the Economy. , ed. Susan L. Averett, Laura M. Argys and Saul D. Hoffman. New York:Oxford University Press.

Bloch, Francis, and Vijayendra Rao. 2002. "Terror as a Bargaining Instrument: A Case Study of Dowry Violence in Rural India." The American Economic Review, 92(4): 10291043.

Brandt, Loren, Aloysius Siow, and Carl Vogel. 2016. "Large Demographic Shocks and Small Changes in the Marriage Market." Journal of the European Economic Association, 14(6): 1437-1468.

Caruso, Germán, and Sebastian Miller. 2015. "Long Run Effects and Intergenerational Transmission of Natural Disasters: A Case Study on the 1970 Ancash Earthquake." Journal of Development Economics, 117: 134-150.

Caruso, Germán Daniel. 2017. "The Legacy of Natural Disasters: The Intergenerational Impact of 100 years of Disasters in Latin America." Journal of Development Economics, 127: $209-233$.

Chiplunkar, Gaurav, and Jeffrey Weaver. 2017. "Marriage Markets and the Rise of Dowry in India." Unpublished Manuscript.

Cohan, Catherine L., and Steve W. Cole. 2002. "Life Course Transitions and Natural Disaster: Marriage, Birth, and Divorce Following Hurricane Hugo." Journal of Family Psychology, 16(1): 14-25. 
Corno, Lucia, Nicole Hildebrandt, and Alessandra Voena. 2017. "Age of Marriage, Weather Shocks, and the Direction of Marriage Payments." National Bureau of Economic Research Working Paper 23604.

Dasgupta, Shatanjaya. 2014. "Women's Partner Choices and Gender Relations in India." Indian Journal of Economics 85 Business, 13(3): 381-403.

Datar, Ashlesha, Jenny Liu, Sebastian Linnemayr, and Chad Stecher. 2013. "The Impact of Natural Disasters on Child Health and Investments in Rural India." Social Science \&3 Medicine, 76: 83-91.

Do, Quy-Toan, Sriya Iyer, and Shareen Joshi. 2013. "The Economics of Consanguineous Marriages." Review of Economics and Statistics, 95(3): 904-918.

Finlay, Jocelyn E. 2009. "Fertility Response to Natural Disasters: The Case of Three High Mortality Earthquakes.” World Bank Policy Research Working Paper 4883.

Frankenberg, Elizabeth, Maria Laurito, and Duncan Thomas. 2014. "The Demography of Disasters." In International Encyclopedia of the Social and Behavioral Science (Area 3). North Holland, Amsterdam.

Hamamatsu, Yuri, Yosuke Inoue, Chiho Watanabe, and Masahiro Umezaki. 2014. "Impact of the 2011 Earthquakes on Marriages, Births and Secondary Sex Ratio in Japan." Journal of Biosocial Science, 46(6): 830-841.

Heger, Martin, Alex Julca, and Oliver Paddison. 2008. "Analysing the Impact of Natural Hazards in Small Economies: The Caribbean Case." World Institute for Development Economic Research (UNU-WIDER) WIDER Working Paper Series 025.

Jensen, Robert, and Rebecca Thornton. 2003. "Early Female Marriage in the Developing World." Gender 83 Development, 11(2): 9-19.

Kahn, Matthew E. 2005. "The Death Toll From Natural Disasters: The Role of Income, Geography, and Institutions." The Review of Economics and Statistics, 87(2): 271-284.

Lahiri, Ashok K., Tapas K. Sen, R. Kavita Rao, and Pratap Ranjan Jana. 2001. "Economic Consequences of Gujarat Earthquake." Economic and Political Weekly, 36(1): 1319-1332.

Lynham, John, Ilan Noy, and Jonathan Page. 2017. "The 1960 Tsunami in Hawaii: Long-Term Consequences of a Coastal Disaster." World Development, 94: 106-118. 
Madabhushi, S.P.G., and S. K. Haigh. 2005. "The Bhuj, India Earthquake of 26th January 2001." A Field Report by EEFIT, Earthquake Engineering Filed Investigation Team, London.

Mazumdar, Sumit, Papiya Guha Mazumdar, Barun Kanjilal, and Prashant Kumar Singh. 2014. "Multiple Shocks, Coping and Welfare Consequences: Natural Disasters and Health Shocks in the Indian Sundarbans." PLoS One, 9(8): e105427.

Mobarak, Ahmed Mushfiq, Randall Kuhn, and Christina Peters. 2013. "Consanguinity and Other Marriage Market Effects of a Wealth Shock in Bangladesh." Demography, 50(5): 1845-1871.

Munshi, Kaivan, and Mark Rosenzweig. 2009. "Why is Mobility in India so Low? Social Insurance, Inequality and Growth." National Bureau of Economic Research Working Paper 14850 .

Nandi, Arindam, Sumit Mazumdar, and Jere R. Behrman. 2018. "The Effect of Natural Disaster on Fertility, Birth Spacing, and Child Sex Ratio: Evidence from a Major Earthquake in India." Journal of Population Economics, 31(1): 267-293.

Narayan, J.P., and M. L. Sharma. 2004. "Effects of Local Geology on Damage Severity During Bhuj, India Earthquake." $13^{\text {th }}$ World Conference on Earthquake Engineering, Vancouver B.C., Canada, Paper No. 2042.

Neumayer, Eric, and Thomas Plümper. 2007. "The Gendered Nature of Natural Disasters: The Impact of Catastrophic Events on the Gender Gap in Life Expectancy, 19812002." Annals of the Association of American Geographers, 97(3): 551-566.

Nobles, Jenna, Elizabeth Frankenberg, and Duncan Thomas. 2015. "The Effects of Mortality on Fertility: Population Dynamics After a Natural Disaster." Demography, 52(1): 15-38.

Noy, Ilan. 2009. "The macroeconomic consequences of disasters." Journal of Development Economics, 88.

Paudel, Jayash, and Hanbyul Ryu. 2018. "Natural disasters and human capital: The case of Nepal?s earthquake." World Development, 111: 1 - 12.

Ritchie, Hannah, and Max Roser. 2019. "Natural Disasters." Our World in Data. https://ourworldindata.org/natural-disasters. 
Roy, Sanchari. 2015. "Empowering Women? Inheritance Rights, Female Education and Dowry Payments in India." Journal of Development Economics, 114: 233-251.

Rubio, Gabriela. 2014. "How Love Conquered Marriage: Theory and Evidence on the Disappearance of Arranged marriages." Unpublished Manuscript.

Saadat, Mostafa. 2008. "Decline in Sex Ratio at Birth after Bam (Kerman Province, Southern Iran) Earthquake." Journal of Biosocial Science, 40(6): 935-937.

Shemyakina, Olga. 2009. "The Marriage Market and Tajik Armed Conflict." HiCN Working Paper 66.

Sinha, Anil K. 2001. "The Gujarat Earthquake 2001." Asian Disaster Reduction Center Report.

Skidmore, Mark, and Hideki Toya. 2002. "Do Natural Disasters Promote Long-Run Growth?" Economic Inquiry, 40(4): 664-687.

Strobl, Eric. 2012. "The economic growth impact of natural disasters in developing countries: Evidence from hurricane strikes in the Central American and Caribbean regions." Journal of Development Economics, 97(1): 130 - 141.

Takasaki, Yoshito. 2017. "Do Natural Disasters Decrease the Gender Gap in Schooling?" World Development, 94: 75-89.

Thamarapani, Dhanushka. 2017. "The Long-Run Effects of the Yogyakarta Earthquake on Child Health Outcomes." Working Paper.

Torche, Florencia. 2011. "The Effect of Maternal Stress on Birth Outcomes: Exploiting a Natural Experiment." Demography, 48(4): 1473-1491.

United Nations. 2015. "Global Assessment Report on Disaster Risk Reduction 2015." United Nations Office for Disaster Risk Reduction Report.

Yang, Dean. 2008. "Coping with Disaster: The Impact of Hurricanes on International Financial Flows, 1970-2002." The B.E. Journal of Economic Analysis 83 Policy, 8(1): 145.

Zhao, Zhongwei, and Anna Reimondos. 2012. "The Demography of China's 1958-61 Famine: A Closer Examination." Population (English Edition), 67(2): 281-308. 
Figure 1: Map showing affected and unaffected districts

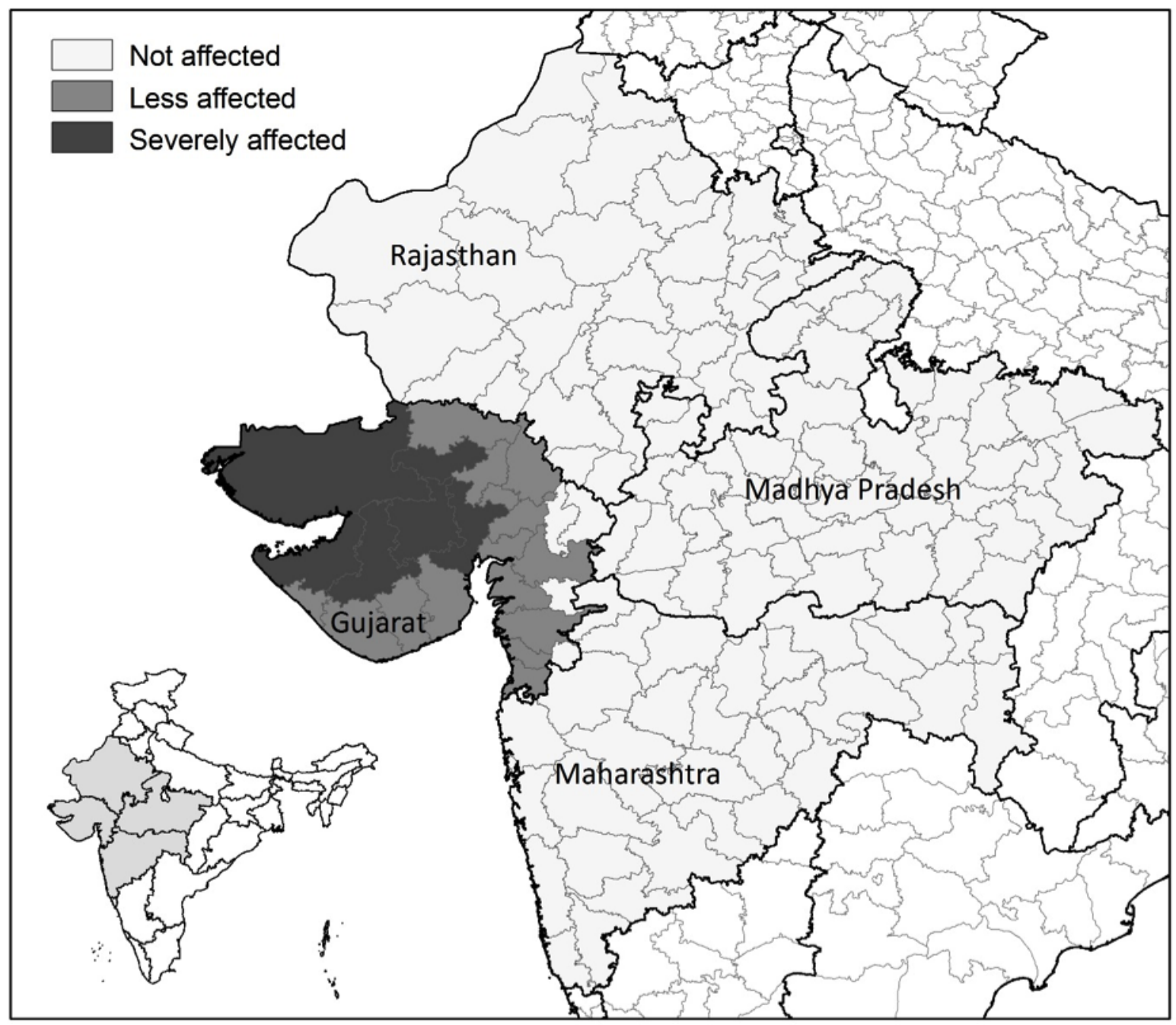

Notes: Based on information from Lahiri et al. (2001). Severely affected districts in Gujarat include Ahmedabad, Jamnagar, Kutch, Patan, Rajkot, and Surendranagar. Less affected districts are: Amrelli, Anand, Banaskantha, Bharuch, Bhavnagar, Gandhinagar, Junagadh, Kheda, Mehsana, Navasari, Porbandar, Sabarkantha, Surat, Vadodara, and Valsad. The four unaffected districts in Gujarat are Dahod, Dangs, Narmada, and Panch Mahals. This map was created using ArcGIS (version 10.3). GIS shapefiles were downloaded from https://international.ipums.org/ international/. 
Table 1:

Summary Statistics of Affected and Unaffected Districts

\begin{tabular}{|c|c|c|c|c|}
\hline & \multicolumn{2}{|c|}{ Affected } & \multicolumn{2}{|c|}{ Unaffected } \\
\hline & $\begin{array}{c}\text { Mean } \\
(1)\end{array}$ & $\begin{array}{l}\text { SD } \\
(2) \\
\end{array}$ & $\begin{array}{c}\text { Mean } \\
(3)\end{array}$ & $\begin{array}{l}\text { SD } \\
(4) \\
\end{array}$ \\
\hline Age of woman & 24.34 & 3.65 & 23.04 & 3.33 \\
\hline Age of spouse & 28.23 & 4.36 & 27.45 & 4.26 \\
\hline Education of woman & 6.65 & 5.14 & 5.84 & 4.82 \\
\hline Education of spouse & 8.62 & 4.62 & 8.07 & 4.33 \\
\hline Log of Household Total Income & 10.64 & 1.08 & 10.49 & 0.97 \\
\hline Log of Monthly Consumption Per Capita & 6.75 & 0.59 & 6.40 & 0.64 \\
\hline Urban & 0.51 & 0.50 & 0.33 & 0.47 \\
\hline \multicolumn{5}{|l|}{ Religion } \\
\hline Hindu & 0.86 & 0.35 & 0.87 & 0.34 \\
\hline Muslim & 0.13 & 0.33 & 0.08 & 0.27 \\
\hline Other & 0.02 & 0.13 & 0.05 & 0.21 \\
\hline \multicolumn{5}{|l|}{ Caste } \\
\hline General & 0.41 & 0.49 & 0.32 & 0.47 \\
\hline Scheduled Caste (SC) & 0.11 & 0.32 & 0.21 & 0.41 \\
\hline Scheduled Tribe (ST) & 0.05 & 0.22 & 0.11 & 0.32 \\
\hline Other Backward Classes (OBC) & 0.42 & 0.49 & 0.36 & 0.48 \\
\hline Observations & \multicolumn{2}{|c|}{436} & \multicolumn{2}{|c|}{1753} \\
\hline
\end{tabular}


Table 2:

Descriptive Statistics of Outcome Variables for Affected and Unaffected Districts

\begin{tabular}{|c|c|c|c|c|c|c|}
\hline & \multicolumn{3}{|c|}{ Affected } & \multicolumn{3}{|c|}{ Unaffected } \\
\hline & $\begin{array}{c}\text { Mean } \\
(1)\end{array}$ & $\begin{array}{l}\mathrm{SD} \\
(2) \\
\end{array}$ & $\begin{array}{l}\mathbf{N} \\
(3) \\
\end{array}$ & $\begin{array}{c}\text { Mean } \\
(4) \\
\end{array}$ & $\begin{array}{l}\mathrm{SD} \\
(5)\end{array}$ & $\begin{array}{l}\mathbf{N} \\
(6) \\
\end{array}$ \\
\hline Woman's Age at Marriage & 19.02 & 2.93 & 436 & 17.80 & 2.90 & 1,753 \\
\hline Spouse Age at Marriage & 22.91 & 3.47 & 436 & 22.21 & 3.89 & 1,753 \\
\hline Age Difference & 3.89 & 2.50 & 436 & 4.41 & 2.53 & 1,753 \\
\hline Spouse from Same Village & 0.09 & 0.29 & 435 & 0.11 & 0.31 & 1,744 \\
\hline Spouse from Same Caste & 0.90 & 0.30 & 435 & 0.98 & 0.15 & 1,748 \\
\hline Difference in Education & 1.97 & 3.37 & 436 & 2.23 & 3.84 & 1,753 \\
\hline Spouse More Educated & 0.56 & 0.50 & 436 & 0.58 & 0.49 & 1,753 \\
\hline Spouse Family Worse Off-status & 0.07 & 0.26 & 436 & 0.07 & 0.26 & 1,753 \\
\hline Self-arranged Marriage & 0.11 & 0.31 & 436 & 0.03 & 0.16 & 1,750 \\
\hline Parent-arranged Marriage with Consent & 0.85 & 0.35 & 434 & 0.60 & 0.49 & 1,738 \\
\hline Parent-arranged Marriage without Consent & 0.04 & 0.19 & 434 & 0.38 & 0.48 & 1,738 \\
\hline Knew Spouse & 0.37 & 0.48 & 434 & 0.20 & 0.40 & 1,748 \\
\hline Related to Spouse & 0.09 & 0.29 & 189 & 0.19 & 0.39 & 1,376 \\
\hline
\end{tabular}




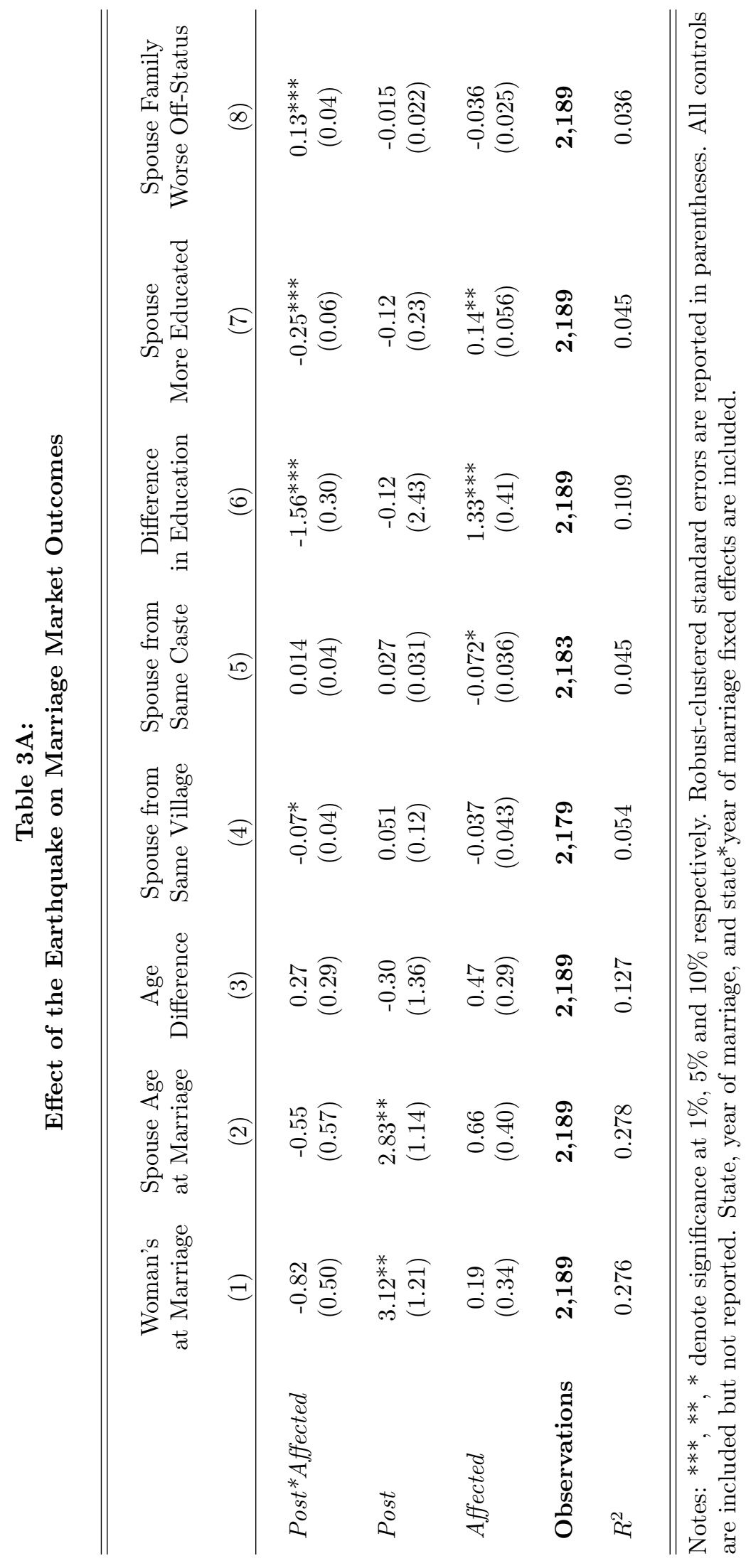


Table 3B:

Effect of the Earthquake on Marriage Market Outcomes

\begin{tabular}{lccccc}
\hline \hline & Self-Arranged & $\begin{array}{c}\text { Parent Arranged } \\
\text { with Consent }\end{array}$ & $\begin{array}{c}\text { Parent arranged } \\
\text { without Consent }\end{array}$ & $\begin{array}{c}\text { Knew } \\
\text { Spouse }\end{array}$ & $\begin{array}{c}\text { Related to } \\
\text { Spouse }\end{array}$ \\
& $(1)$ & $(2)$ & $(3)$ & $(4)$ & $(5)$ \\
\hline Post ${ }^{*}$ Affected & $-0.26^{* * *}$ & $0.28^{* * *}$ & -0.026 & 0.021 & $0.17^{*}$ \\
& $(0.023)$ & $(0.031)$ & $(0.020)$ & $(0.068)$ & $(0.085)$ \\
Post & -0.011 & 0.28 & -0.26 & 0.018 & 0.020 \\
& $(0.011)$ & $(0.25)$ & $(0.25)$ & $(0.10)$ & $(0.032)$ \\
Affected & $0.11^{* * *}$ & $-0.30^{* * *}$ & $0.18^{* * *}$ & $-0.46^{* * *}$ & $-0.16^{* *}$ \\
& $(0.039)$ & $(0.082)$ & $(0.067)$ & $(0.086)$ & $(0.073)$ \\
Observations & $\mathbf{2 , 1 8 6}$ & $\mathbf{2 , 1 7 2}$ & $\mathbf{2 , 1 7 2}$ & $\mathbf{2 , 1 8 2}$ & $\mathbf{1 , 5 6 5}$ \\
$R^{2}$ & 0.045 & 0.251 & 0.335 & 0.112 & 0.122 \\
\hline
\end{tabular}

Notes: ***,**,* denote significance at $1 \%, 5 \%$ and $10 \%$ respectively. Robust-clustered standard errors are reported in parentheses. All controls are included but not reported. State, year of marriage, and state*year of marriage fixed effects are included. 


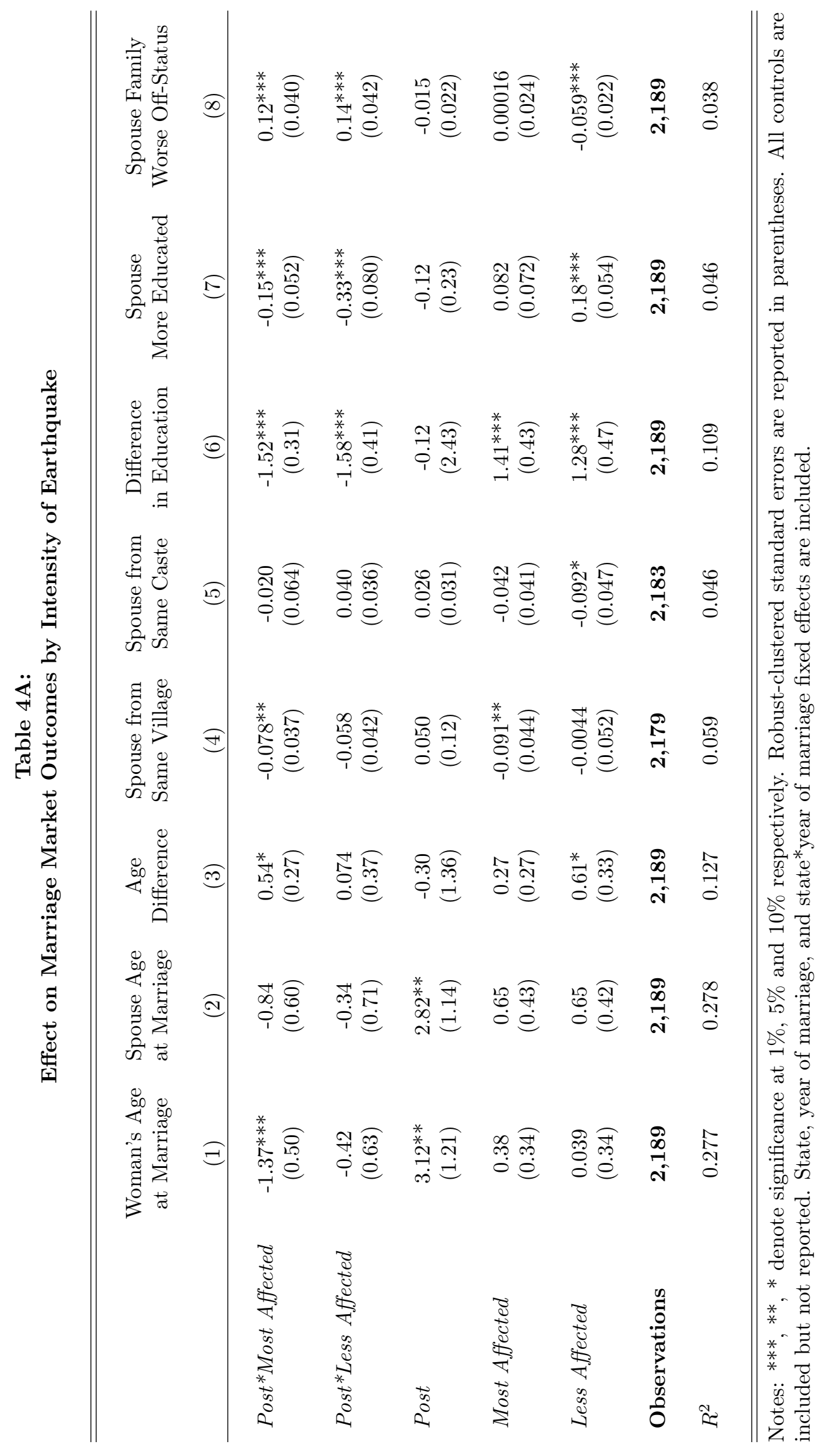


Table 4B:

Effect on Marriage Market Outcomes by Intensity of Earthquake

\begin{tabular}{lccccc}
\hline \hline & Self-Arranged & $\begin{array}{c}\text { Parent Arranged } \\
\text { with Consent }\end{array}$ & $\begin{array}{c}\text { Parent arranged } \\
\text { without Consent }\end{array}$ & $\begin{array}{c}\text { Knew } \\
\text { Spouse }\end{array}$ & $\begin{array}{c}\text { Related to } \\
\text { Spouse }\end{array}$ \\
& $(1)$ & $(2)$ & $(3)$ & $(4)$ & $(5)$ \\
\hline \multirow{2}{*}{ Post ${ }^{*}$ Most Affected } & $-0.24^{* * *}$ & $0.25^{* * *}$ & -0.012 & 0.021 & 0.081 \\
& $(0.026)$ & $(0.026)$ & $(0.021)$ & $(0.11)$ & $(0.092)$ \\
Post ${ }^{*}$ Less Affected & $-0.27^{* * *}$ & $0.31^{* * *}$ & -0.039 & 0.016 & $0.23^{* *}$ \\
& $(0.028)$ & $(0.044)$ & $(0.029)$ & $(0.063)$ & $(0.058)$ \\
Post & -0.011 & 0.28 & -0.26 & 0.018 & 0.020 \\
& $(0.011)$ & $(0.25)$ & $(0.25)$ & $(0.10)$ & $(0.033)$ \\
Most Affected & $0.12^{* *}$ & $-0.27^{* * *}$ & $0.15^{* *}$ & $-0.56^{* * *}$ & -0.093 \\
& $(0.059)$ & $(0.081)$ & $(0.065)$ & $(0.14)$ & $(0.075)$ \\
Less Affected & $0.11^{* * *}$ & $-0.32^{* * *}$ & $0.20^{* *}$ & $-0.40^{* * *}$ & $-0.21^{* * *}$ \\
& $(0.041)$ & $(0.097)$ & $(0.078)$ & $(0.070)$ & $(0.056)$ \\
Observations & $\mathbf{2 , 1 8 6}$ & $\mathbf{2 , 1 7 2}$ & $\mathbf{2 , 1 7 2}$ & $\mathbf{2 , 1 8 2}$ & $\mathbf{1 , 5 6 5}$ \\
$R^{2}$ & 0.046 & 0.251 & 0.336 & 0.118 & 0.124 \\
& & & & \\
\hline \hline
\end{tabular}

Notes: $* * *, * *, *$ denote significance at $1 \%, 5 \%$ and $10 \%$ respectively. Robust-clustered standard errors are reported in parentheses. All controls are included but not reported. State, year of marriage, and state* year of marriage fixed effects are included. 
Table 5:

Mechanism: Effect on Proxy for Dowry Payment

\begin{tabular}{|c|c|c|c|c|c|c|}
\hline & \multicolumn{2}{|c|}{ Full Sample } & \multicolumn{2}{|c|}{ Worse-Off Status } & \multicolumn{2}{|c|}{ Same or Better Status } \\
\hline & $\begin{array}{l}\text { Gold } \\
(1)\end{array}$ & $\begin{array}{c}\text { Cash } \\
(2)\end{array}$ & $\begin{array}{l}\text { Gold } \\
(3)\end{array}$ & $\begin{array}{c}\text { Cash } \\
(4)\end{array}$ & $\begin{array}{l}\text { Gold } \\
(5)\end{array}$ & $\begin{array}{c}\text { Cash } \\
(6)\end{array}$ \\
\hline \multicolumn{7}{|c|}{ Panel A: Full Sample } \\
\hline Post ${ }^{*}$ Affected & $\begin{array}{c}0.34^{* * *} \\
(0.016)\end{array}$ & $\begin{array}{c}0.20^{* * *} \\
(0.052)\end{array}$ & $\begin{array}{c}-0.75^{* *} \\
(0.37)\end{array}$ & $\begin{array}{c}0.46 \\
(0.41)\end{array}$ & $\begin{array}{c}0.30 * * * \\
(0.017)\end{array}$ & $\begin{array}{c}0.20^{* * *} \\
(0.055)\end{array}$ \\
\hline Observations & 2,185 & 2,170 & 156 & 156 & 2,029 & 2,014 \\
\hline$R^{2}$ & 0.141 & 0.086 & 0.333 & 0.416 & 0.157 & 0.082 \\
\hline \multicolumn{7}{|c|}{ Panel B: By Intensity of Treatment } \\
\hline Post*Most Affected & $\begin{array}{c}0.34^{* * *} \\
(0.019)\end{array}$ & $\begin{array}{c}0.14^{*} \\
(0.075)\end{array}$ & $\begin{array}{c}-0.53^{* *} \\
(0.25)\end{array}$ & $\begin{array}{c}0.38 \\
(0.46)\end{array}$ & $\begin{array}{c}0.29 * * * \\
(0.015)\end{array}$ & $\begin{array}{c}0.13 \\
(0.10)\end{array}$ \\
\hline Post ${ }^{*}$ Less Affected & $\begin{array}{c}0.34^{* * *} \\
(0.025)\end{array}$ & $\begin{array}{c}0.24^{* * *} \\
(0.063)\end{array}$ & $\begin{array}{c}-1.03^{* *} \\
(0.39)\end{array}$ & $\begin{array}{c}0.63 \\
(0.60)\end{array}$ & $\begin{array}{c}0.31^{* * *} \\
(0.025)\end{array}$ & $\begin{array}{c}0.25^{* * *} \\
(0.061)\end{array}$ \\
\hline Observations & 2,185 & 2,170 & 156 & 156 & 2,029 & 2,014 \\
\hline$R^{2}$ & 0.141 & 0.091 & 0.357 & 0.419 & 0.157 & 0.088 \\
\hline
\end{tabular}

Notes: $* * *, * *, *$ denote significance at $1 \%, 5 \%$ and $10 \%$ respectively. Robust-clustered standard errors are reported in parentheses. All controls are included but not reported. State, year of marriage, and state* year of marriage fixed effects are included. Columns (1) and (2) present results for the full sample, Columns (3) and (4) for when a woman marries into a poorer household, and finally Columns (5) and (6) present results for when a woman's marital family is of similar or better off economic status as that of her natal family. 


\section{A Appendix Tables}

Table A1:

Robustness Check: Simulating False Location for Earthquake

\begin{tabular}{|c|c|c|c|}
\hline & $\begin{array}{l}\text { Rajasthan } \\
\text { as treatment } \\
\text { (1) }\end{array}$ & $\begin{array}{c}\text { Maharashtra } \\
\text { as treatment } \\
\text { (2) }\end{array}$ & $\begin{array}{c}\text { Madhya Pradesh } \\
\text { as treatment } \\
\text { (3) }\end{array}$ \\
\hline Woman's age at marriage & $\begin{array}{c}1.37 \\
(1.29)\end{array}$ & $\begin{array}{l}-1.37 \\
(1.29)\end{array}$ & $\begin{array}{c}1.65 \\
(1.51)\end{array}$ \\
\hline Spouse age at marriage & $\begin{array}{c}0.94 \\
(1.45)\end{array}$ & $\begin{array}{l}-0.94 \\
(1.45)\end{array}$ & $\begin{array}{c}1.11 \\
(1.90)\end{array}$ \\
\hline Age difference & $\begin{array}{l}-0.42 \\
(1.64)\end{array}$ & $\begin{array}{c}0.42 \\
(1.64)\end{array}$ & $\begin{array}{c}-0.54 \\
(1.58)\end{array}$ \\
\hline Spouse from same village & $\begin{array}{l}-0.018 \\
(0.14)\end{array}$ & $\begin{array}{l}0.018 \\
(0.14)\end{array}$ & $\begin{array}{c}0.40 \\
(0.28)\end{array}$ \\
\hline Spouse from same caste & $\begin{array}{c}-0.0028 \\
(0.036)\end{array}$ & $\begin{array}{l}0.0028 \\
(0.036)\end{array}$ & $\begin{array}{c}0.021 \\
(0.036)\end{array}$ \\
\hline Difference in education & $\begin{array}{c}1.38 \\
(2.62)\end{array}$ & $\begin{array}{l}-1.38 \\
(2.62)\end{array}$ & $\begin{array}{l}-1.16 \\
(2.65)\end{array}$ \\
\hline Spouse more educated & $\begin{array}{l}0.088 \\
(0.26)\end{array}$ & $\begin{array}{c}-0.088 \\
(0.26)\end{array}$ & $\begin{array}{l}0.067 \\
(0.34)\end{array}$ \\
\hline Spouse family worse-off status & $\begin{array}{c}0.046 \\
(0.079)\end{array}$ & $\begin{array}{c}-0.046 \\
(0.079)\end{array}$ & $\begin{array}{c}0.017 \\
(0.033)\end{array}$ \\
\hline Self-arranged & $\begin{array}{c}0.034 \\
(0.026)\end{array}$ & $\begin{array}{c}-0.034 \\
(0.026)\end{array}$ & $\begin{array}{c}-0.016 \\
(0.022)\end{array}$ \\
\hline Parent arranged with consent & $\begin{array}{l}0.049 \\
(0.26)\end{array}$ & $\begin{array}{c}-0.049 \\
(0.26)\end{array}$ & $\begin{array}{l}-0.16 \\
(0.37)\end{array}$ \\
\hline Parent arranged w/o consent & $\begin{array}{c}-0.085 \\
(0.26)\end{array}$ & $\begin{array}{l}0.085 \\
(0.26)\end{array}$ & $\begin{array}{c}0.17 \\
(0.37)\end{array}$ \\
\hline Knew spouse & $\begin{array}{l}0.027 \\
(0.13)\end{array}$ & $\begin{array}{r}-0.027 \\
(0.13)\end{array}$ & $\begin{array}{c}0.38 \\
(0.27)\end{array}$ \\
\hline Related to spouse & $\begin{array}{l}-0.041 \\
(0.14)\end{array}$ & $\begin{array}{l}0.041 \\
(0.14)\end{array}$ & $\begin{array}{l}-0.11^{*} \\
(0.064)\end{array}$ \\
\hline
\end{tabular}

Notes: $* * *, * *, *$ denote significance at $1 \%, 5 \%$ and $10 \%$ respectively. Robust-clustered standard errors are reported in parentheses. All controls are included but not reported. State and year of marriage marriage fixed effects are included. Each row represents a separate regression with the dependent variable as given. Only the coefficient on the interaction term Post* Affected is reported. 
Table A2:

Robustness Check: Dropping Control States One at a Time

\begin{tabular}{|c|c|c|c|}
\hline & $\begin{array}{c}\text { Dropping Rajasthan } \\
\text { (1) }\end{array}$ & $\begin{array}{c}\text { Dropping Maharashtra } \\
\qquad(2)\end{array}$ & $\begin{array}{c}\text { Dropping Madhya Pradesh } \\
\text { (3) }\end{array}$ \\
\hline Woman's age at marriage & $\begin{array}{l}-0.82 \\
(0.50)\end{array}$ & $\begin{array}{l}-0.75 \\
(0.48)\end{array}$ & $\begin{array}{l}-0.84^{*} \\
(0.50)\end{array}$ \\
\hline Spouse age at marriage & $\begin{array}{l}-0.58 \\
(0.58)\end{array}$ & $\begin{array}{l}-0.43 \\
(0.56)\end{array}$ & $\begin{array}{l}-0.57 \\
(0.58)\end{array}$ \\
\hline Age difference & $\begin{array}{c}0.24 \\
(0.29)\end{array}$ & $\begin{array}{c}0.32 \\
(0.29)\end{array}$ & $\begin{array}{c}0.26 \\
(0.29)\end{array}$ \\
\hline Spouse from same village & $\begin{array}{l}-0.066^{*} \\
(0.036)\end{array}$ & $\begin{array}{l}-0.059 \\
(0.038)\end{array}$ & $\begin{array}{r}-0.064^{*} \\
(0.036)\end{array}$ \\
\hline Spouse from same caste & $\begin{array}{c}0.013 \\
(0.040)\end{array}$ & $\begin{array}{c}0.013 \\
(0.041)\end{array}$ & $\begin{array}{c}0.014 \\
(0.040)\end{array}$ \\
\hline Difference in education & $\begin{array}{c}-1.52^{* * *} \\
(0.29)\end{array}$ & $\begin{array}{c}-1.73^{* * *} \\
(0.33)\end{array}$ & $\begin{array}{c}-1.55^{* * *} \\
(0.29)\end{array}$ \\
\hline Spouse more educated & $\begin{array}{c}-0.25^{* * *} \\
(0.060)\end{array}$ & $\begin{array}{c}-0.27^{* * *} \\
(0.062)\end{array}$ & $\begin{array}{c}-0.26^{* * *} \\
(0.060)\end{array}$ \\
\hline Spouse family worse off status & $\begin{array}{c}0.13^{* * *} \\
(0.037)\end{array}$ & $\begin{array}{c}0.14^{* * *} \\
(0.037)\end{array}$ & $\begin{array}{c}0.13^{* * *} \\
(0.036)\end{array}$ \\
\hline Self-arranged & $\begin{array}{c}-0.25^{* * *} \\
(0.023)\end{array}$ & $\begin{array}{c}-0.26^{* * *} \\
(0.022)\end{array}$ & $\begin{array}{c}-0.25^{* * *} \\
(0.022)\end{array}$ \\
\hline Parent arranged with consent & $\begin{array}{c}0.28^{* * *} \\
(0.032)\end{array}$ & $\begin{array}{c}0.29^{* * *} \\
(0.035)\end{array}$ & $\begin{array}{r}0.28^{* * *} \\
(0.029)\end{array}$ \\
\hline Parent arranged w/o consent & $\begin{array}{l}-0.027 \\
(0.021)\end{array}$ & $\begin{array}{l}-0.023 \\
(0.023)\end{array}$ & $\begin{array}{l}-0.023 \\
(0.020)\end{array}$ \\
\hline Knew spouse & $\begin{array}{c}0.021 \\
(0.068)\end{array}$ & $\begin{array}{c}0.027 \\
(0.064)\end{array}$ & $\begin{array}{c}0.027 \\
(0.068)\end{array}$ \\
\hline Related to spouse & $\begin{array}{c}0.17^{*} \\
(0.087)\end{array}$ & $\begin{array}{c}0.15^{*} \\
(0.077)\end{array}$ & $\begin{array}{c}0.17^{*} \\
(0.088)\end{array}$ \\
\hline
\end{tabular}

Notes: $* * *, * *, *$ denote significance at $1 \%, 5 \%$ and $10 \%$ respectively. Robust-clustered standard errors are reported in parentheses. All controls are included but not reported. State and year of marriage marriage fixed effects are included. Each row represents a separate regression with the dependent variable as given. Only the coefficient on the interaction term Post* Affected is reported. 
Table A3:

Testing Sensitivity of Results to Choice of Study Time Period

\begin{tabular}{|c|c|c|}
\hline & $\begin{array}{c}1998-2003 \\
(1)\end{array}$ & $\begin{array}{c}1991-2005 \\
(2)\end{array}$ \\
\hline Woman's age at marriage & $\begin{array}{c}-1.40^{* *} \\
(0.60)\end{array}$ & $\begin{array}{l}-0.33 \\
(0.48)\end{array}$ \\
\hline Spouse age at marriage & $\begin{array}{l}-1.02 \\
(0.68)\end{array}$ & $\begin{array}{c}0.49 \\
(0.49)\end{array}$ \\
\hline Age difference & $\begin{array}{c}0.38 \\
(0.24)\end{array}$ & $\begin{array}{c}0.81^{* * *} \\
(0.28)\end{array}$ \\
\hline Spouse from same village & $\begin{array}{c}-0.11^{* * *} \\
(0.032)\end{array}$ & $\begin{array}{l}0.0076 \\
(0.032)\end{array}$ \\
\hline Spouse from same caste & $\begin{array}{c}0.002 \\
(0.044)\end{array}$ & $\begin{array}{c}0.028 \\
(0.029)\end{array}$ \\
\hline Difference in education & $\begin{array}{c}-1.08^{* *} \\
(0.44)\end{array}$ & $\begin{array}{c}-1.79^{* * *} \\
(0.29)\end{array}$ \\
\hline Spouse more educated & $\begin{array}{c}-0.24 * * * \\
(0.085)\end{array}$ & $\begin{array}{c}-0.30^{* * *} \\
(0.049)\end{array}$ \\
\hline Spouse family worse off status & $\begin{array}{c}0.095^{* *} \\
(0.038)\end{array}$ & $\begin{array}{c}0.12^{* * *} \\
(0.035)\end{array}$ \\
\hline Self-arranged & $\begin{array}{c}-0.30^{* * *} \\
(0.021)\end{array}$ & $\begin{array}{c}-0.21^{* * *} \\
(0.019)\end{array}$ \\
\hline Parent arranged with consent & $\begin{array}{c}0.32^{* * *} \\
(0.028)\end{array}$ & $\begin{array}{c}0.23^{* * *} \\
(0.024)\end{array}$ \\
\hline Parent arranged w/o consent & $\begin{array}{l}-0.025 \\
(0.022)\end{array}$ & $\begin{array}{l}-0.019 \\
(0.016)\end{array}$ \\
\hline Knew spouse & $\begin{array}{l}-0.095 \\
(0.093)\end{array}$ & $\begin{array}{c}0.051 \\
(0.054)\end{array}$ \\
\hline Related to spouse & $\begin{array}{c}0.23^{* *} \\
(0.10)\end{array}$ & $\begin{array}{l}0.13^{* *} \\
(0.057)\end{array}$ \\
\hline
\end{tabular}

Notes: $* * *, * *, *$ denote significance at $1 \%, 5 \%$ and $10 \%$ respectively. Robust-clustered standard errors are reported in parentheses. All controls are included but not reported. State and year of marriage marriage fixed effects are included. Each row represents a separate regression with the dependent variable as given. Only the coefficient on the interaction term Post ${ }^{*}$ Affected is reported. 
Table A4:

Testing Parallel Trends Assumption

\begin{tabular}{|c|c|}
\hline & $\begin{array}{c}t * \text { Affected } \\
(1)\end{array}$ \\
\hline Woman's age at marriage & $\begin{array}{l}-0.031 \\
(0.051)\end{array}$ \\
\hline Spouse age at marriage & $\begin{array}{c}0.014 \\
(0.054)\end{array}$ \\
\hline Age difference & $\begin{array}{c}0.045 \\
(0.040)\end{array}$ \\
\hline Spouse from same village & $\begin{array}{c}0.007 \\
(0.007)\end{array}$ \\
\hline Spouse from same caste & $\begin{array}{c}0.002 \\
(0.004)\end{array}$ \\
\hline Difference in education & $\begin{array}{c}0.033 \\
(0.050)\end{array}$ \\
\hline Spouse more educated & $\begin{array}{l}<0.000 \\
(0.007)\end{array}$ \\
\hline Spouse family worse off status & $\begin{array}{l}-0.003 \\
(0.005)\end{array}$ \\
\hline Self Arranged Marriage & $\begin{array}{c}0.002 \\
(0.004)\end{array}$ \\
\hline Parent arranged marriage with consent & $\begin{array}{c}-0.015^{* * *} \\
(0.005)\end{array}$ \\
\hline Parent arranged marriage without consent & $\begin{array}{c}0.013^{* * *} \\
(0.005)\end{array}$ \\
\hline Knew husband & $\begin{array}{c}0.011 \\
(0.008)\end{array}$ \\
\hline Related to husband & $\begin{array}{c}0.001 \\
(0.008)\end{array}$ \\
\hline
\end{tabular}

Notes: ${ }^{* * *}, * *, *$ denote significance at $1 \%, 5 \%$ and $10 \%$ respectively. Robust-clustered standard errors are reported in parentheses. All controls are included but not reported. State and year of marriage marriage fixed effects are included. Each row represents a separate regression with the dependent variable as given. 